\title{
Benefits Associated with the Interaction of Endophytic Bacteria and Plants
}

\author{
Miriam Langner dos Santos ${ }^{1 *}$, Diouneia Lisiane Berlitz ${ }^{2,5}$, Shana Leticia Felice Wiest ${ }^{1}$, \\ Rogerio Schünemann ${ }^{3}$, Neiva Knaak ${ }^{4}$, Lidia Mariana Fiuza ${ }^{4}$ \\ ${ }^{1}$ Universidade do Vale do Rio dos Sinos - Programa de Pós Graduação de em Biologia, São Leopoldo, Rio Grande \\ do Sul, Brasil. ${ }^{2}$ Instituto Federal de Educação Ciência e Tecnologia do Rio do Grande do Sul, Bento Gonçalves, Rio \\ Grande do Sul, Brasil. ${ }^{3}$ Universidade do Vale do Rio dos Sinos - Biologia, São Leopoldo, Rio Grande do Sul, Brasil. \\ ${ }^{4}$ Instituto Rio Grandense do Arroz, Cachoerinha, Rio Grande do Sul, Brasil. ${ }^{5}$ DLB Soluções Biológicas, consultoria \\ e assessoria, Bento Gonçalves, Rio Grande do Sul, Brasil.
}

\begin{abstract}
The endophytic bacteria belong to a larger group of microorganisms that have their life-cycle partly or entirely inside the plant and are located in intra and inter-cellular spaces or in the vascular tissue. These bacteria can be found colonizing aerial parts or roots. This review aims to analyze the colonization strategies of endophytic bacteria through interaction with plants, as well as to highlight the metabolic influence of these organisms in plant tissues, which result in physiological and biochemical changes. Depending on the different mechanisms used internally to colonize a plant, these microorganisms are called obligate, facultative, or passive endophytes. Phytostimulation, biofertilization and biological control are mechanisms that result in the development of the plant through the production of plant hormones, bioavailability of nutrients and antagonistic action to phytopathogens, respectively. The association between endophytic bacteria and plants features important benefits such as significant increases in growth, plant biomass, length of roots, dry matter production, and grain yield. Studies show that there is a great diversity of endophytic bacteria colonizing plant structures that result in several benefits to the host plant.
\end{abstract}

Keywords: biofertilization, biological control, colonization strategies, microorganisms, phytostimulation.

\footnotetext{
*Author for correspondence: milangner@yahoo.com.br
} 


\section{INTRODUCTION}

Presumably, all plant species have associations with endophytic bacterial communities, maintaining an interaction called plant-endophyte. The endophytic bacteria belong to a larger group of microorganisms that have their life-cycle partly or entirely inside the plant. Generally, these microorganisms are located in intra and inter-cellular spaces or in the vascular tissue, and can be found colonizing aerial parts or roots $(1,2,3,4)$.

Fastidious vascular bacteria are pathogens that are difficult to cultivate in the laboratory. They grow in xylem or phloem tissues, and interfere with transport of water and nutrients to plants, causing diseases $\left(^{5}\right)$. Endophytic bacteria differ from epiphytic microorganisms by colonizing the interior of plants, and from plant pathogens by not causing visible damage to the host plant. This colonization occurs at some stage of the phenological development of the plant $\left(^{6}\right)$. The presence of these non-pathogenic microorganisms was described in plant tissues analyzed under a microscope $\left({ }^{7}\right)$.

Endophytic bacteria are considered as an intermediate group between saprophytic pathogenic bacteria $\left({ }^{8}\right)$. When considering the evolutionary scale, it is apparent that over time microorganisms that started using the interaction with plants beyond just the nutritional benefits provided caused less damage to their host $\left({ }^{9}\right)$.

This review aims to analyze the metabolic influence of endophytic bacteria associated with plant species, as well as to highlight the colonization strategies used by these microorganisms in interaction with plants, which result in physiological and biochemical changes, triggering the plant growth.

\section{INTERACTION BENEFITS ASSOCIATED TO THE PLANT AND ENDOPHYTIC BACTERIA}

The interaction between endophyte and plant is characterized as a symbiotic relationship because both are benefited in this association. The host plant provides niches of protection to the microorganisms which, in turn, produce metabolites that increase the absorption of nutrients, affecting the plant growth and biomass gain. Metabolites compounds induce a resistance process of the plant to pathogens, reducing its exposure to pathogenic infections and acting as disease controllers $\left({ }^{4,10}\right)$.

The interaction between the host plants and the endophytic community involves a process of co-evolution governed by colonization, which is influenced by genotype, growth stage, physiological status, type of plant tissue, agricultural practices, and environmental conditions such as temperature, water supply, and nutrients $\left({ }^{11}\right)$. This evolutionary process results in the existence of an intimate relationship between endophyte and its host, and this interaction is caused by changes in cellular and molecular levels that interfere in the development of the plant $\left({ }^{12,13}\right)$. These mutualistic/symbiotic interactions existing between plants and microorganisms result in a positive selection in consequence of these associations $\left({ }^{14}\right)$.

The endophytic bacteria act directly on the development and growth of plants by biological nitrogen fixation, acceleration of digestion, phosphorus solubilization, and production of phytohormones, which confer resistance to biotic factors. From the indirect stimulation, endophytes promote the improving of availability and absorption of nutrients, minerals and water; induce the tolerance of the host to stress caused by abiotic factors, including osmotic stress, exposure to heavy metals and xenobiotic molecules; assist in the suppression of harmful microorganisms; and act in the biological control of plant pathogens $\left({ }^{4,10,15}\right)$.

The interaction between plants and beneficial bacteria can have a profound effect on plant health, growth, development, production and on soil quality $\left({ }^{16}\right)$. These biological interactions provide several benefits to the involved species and trigger many positive 
impacts on the integrity and sustainability of agro-ecosystems, increasing the agricultural income $\left({ }^{4}\right.$ ), thus highlighting the significant increase in growth, plant biomass, dry matter yield and grain yield (Table 1).

Artificial inoculation of endophytic bacteria in plants can significantly reduce the attack of pathogens, such as fungi, bacteria and virus, as well as insects and nematodes, acting in the biological control of these pathogens $\left({ }^{17}\right)$.

Table 1 Benefits resulting from the association of endophytic bacteria and plants.

\begin{tabular}{|c|c|c|c|}
\hline Host plant & Endophytic bacteria & Associated benefits & References \\
\hline Rice & $\begin{array}{l}\text { Burkholderia sp., Herbaspirillum } \\
\text { seropedicae }\end{array}$ & $\begin{array}{l}\text { increase in grain production; nitrogen } \\
\text { fixation; synthesis of indoleacetic acid } \\
\text { (IAA) }\end{array}$ & 18,19 \\
\hline Beet & $\begin{array}{l}\text { Bacillus pumilus, Chryseobacterium } \\
\text { indologene, Acinetobacter johnsonii }\end{array}$ & increased concentration of carbohydrates & 20 \\
\hline Sugar cane & $\begin{array}{lr}\text { Gluconacetobacter diazotrophicus, } \\
\text { Azospirillum } & \text { amazonense, } \\
\text { Burkholderia } & \text { tropica, } \\
\text { Herbaspirillum } & \text { seropedicae, H. } \\
\text { rubrisubalbicans, G. diazotrophicus }\end{array}$ & $\begin{array}{l}\text { acceleration of budding; increase in } \\
\text { biomass; biological nitrogen fixation; } \\
\text { produce siderophores; IAA synthesis and } \\
\text { phosphate solubilization }\end{array}$ & $21,22,23$ \\
\hline Cabbage & Enterobacter sp., Herbaspirilum sp. & growth promotion & 24 \\
\hline Sunflower & Burkholderia sp. & calcium and phosphate solubilization & 25 \\
\hline Maize & $\begin{array}{l}\text { Azospirillum } r \text { brasilense, } \\
\text { Burkholderia cepacia, Bacillus } \\
\text { subtilis, B. lentimorbus, } \\
\text { Streptomyces sp. } \\
\text { Azospirillum lipoferum }\end{array}$ & $\begin{array}{l}\text { nitrogen fixation; IAA synthesis; growth } \\
\text { promotion; reduction of toluene } \\
\text { evapotranspiration in air; antagonistic } \\
\text { effect to pathogenic fungi; increase in grain } \\
\text { yield }\end{array}$ & $\begin{array}{l}26,27,28, \\
29\end{array}$ \\
\hline Soybean & $\begin{array}{l}\text { Bacillus amyloliquefaciens, } \quad B . \\
\text { japonicum, Azospirillum brasilense }\end{array}$ & $\begin{array}{l}\text { production of siderophores; IAA synthesis; } \\
\text { ACC-deaminase; antifungal activity; } \\
\text { phytases; nitrogen fixation }\end{array}$ & $\underline{30,31}$ \\
\hline Wheat & $\begin{array}{l}\text { B. subtilis, Arthrobacter sp., } \\
\text { Burkholderia cepacia, Azospirillum } \\
\text { sp. }\end{array}$ & $\begin{array}{l}\text { IAA synthesis; phosphate solubilization; } \\
\text { growth promotion; reduction of toluene } \\
\text { evapotranspiration in air; increase in grain } \\
\text { yield }\end{array}$ & $27,29,32$ \\
\hline
\end{tabular}

\section{MECHANISMS USED BY ENDOPHYTIC BACTERIA TO COLONIZE PLANT TISSUES}

The Plant Growth-Promoting Bacteria (PGPB), or Plant Growth-Promoting Rhizobacteria (PGPR), are able to colonize the interior of plants and also have the ability to thrive as endophytes $\left({ }^{16}\right)$. The bacteria that promote growth of plants are associated with the majority of plant species, being able to establish endophytic populations in various tissues and organs of plants without causing any visible sign $\left({ }^{10}\right)$. The endophytic community is subdivided according to the different internal mechanisms used to colonize a plant, receiving the designation of "obligate", "facultative" or "passive" endophytes $\left({ }^{33,34}\right)$. 
Different niches occupied by endophytic bacteria result in different mechanisms used to colonize a plant. Endophytes classified as obligates depend on the plant metabolic activity for their survival. They are transmitted by seed and spread inside the plant by vertical colonization or through the action of a vector. In other words, they are not originated in the rhizosphere. Facultative endophytes have a free life in the soil and colonize the plant internally during some stage of their life cycle. This process occurs through the rhizosphere. Passive endophytes colonize the plant through wounds existing along the root hairs. Due to being adhered to the root surface, they are also called associative bacteria. Moreover, bacteria living in the rhizosphere (rhizobacteria - Figure $1)$, which are closely linked to the plant roots, also occur $\left({ }^{33,34,35}\right)$.

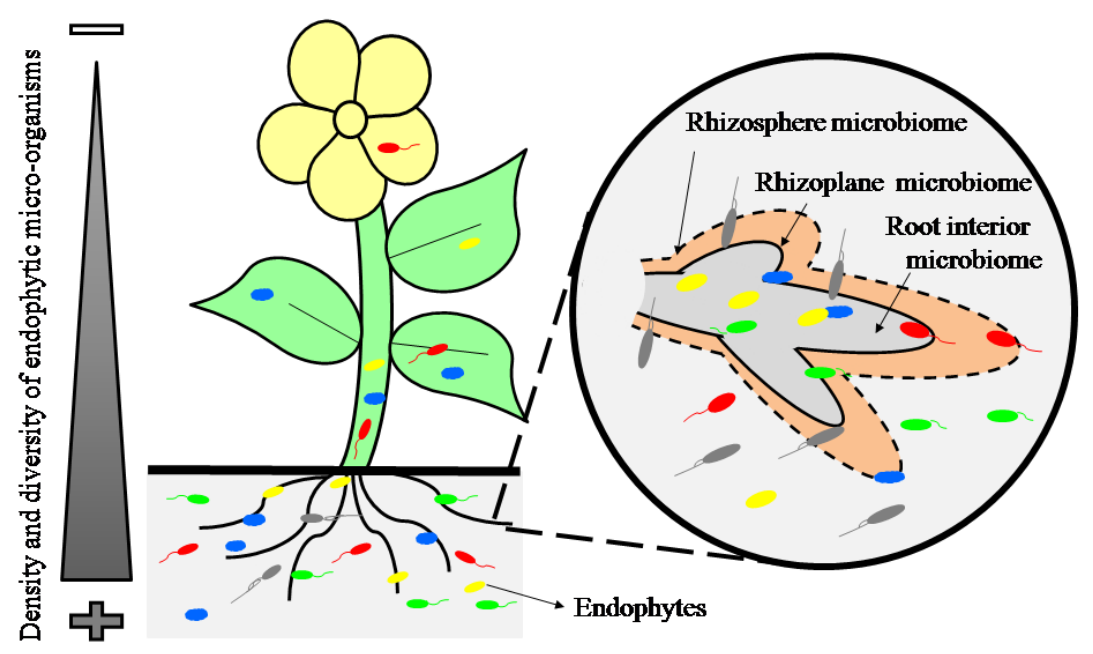

Figure 1. Representation of occurrence of endophytic microorganisms in the aerial parts and roots of plants originating in the rhizosphere, the rhizoplane and the internal root tissue. Source: Adapted from 35 and 33 by the authors

The roots are considered the main gateway to microorganisms and this part of the plant has the highest frequency of endophytic bacteria. The enzymatic activity is a factor which facilitates the penetration of these microorganisms in the plant, which may be transmitted by seed (Figure 2) $\left(^{6,15}\right)$. 


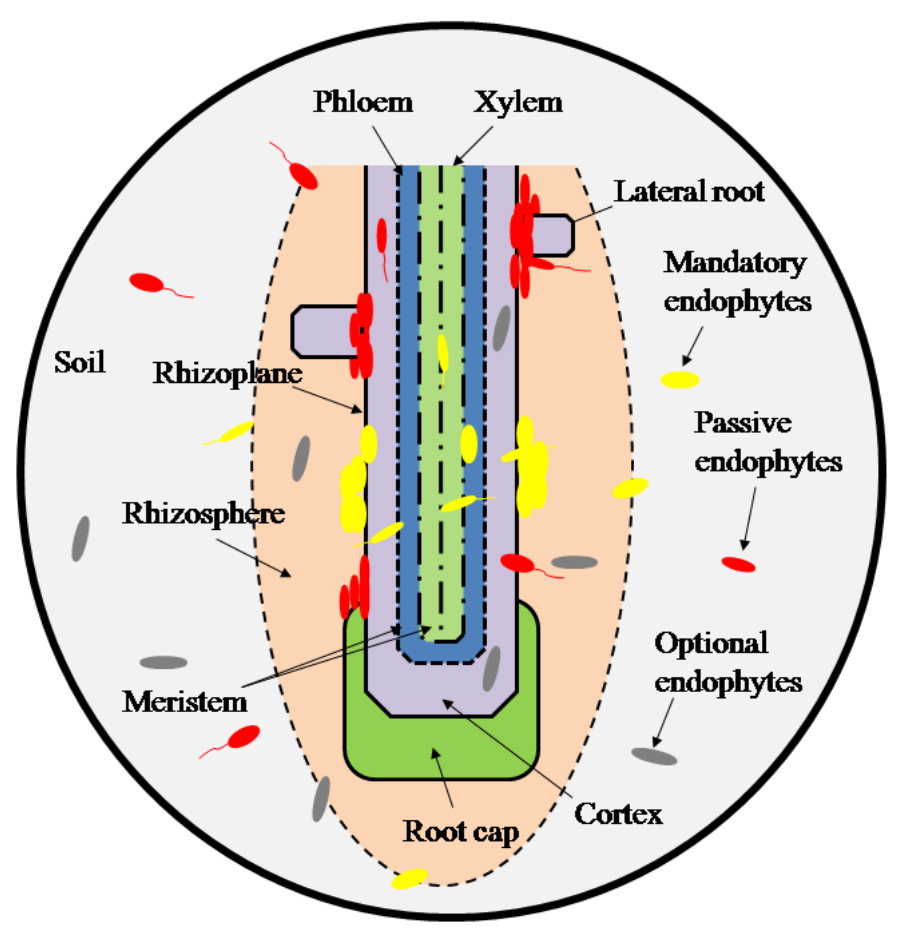

Figure 2. Niches and routes of entry of microorganisms in the roots of plants. Source: Adapted from 13 by he authors.

Structures such as stomata, hydathodes, lenticels (natural openings), nectaries and nectar glands, as well as tissue damage, caused by the attack of insects or broken trichomes, are also entry routes for soil microbiota $\left({ }^{37}\right)$.

The interaction between endophytic bacteria and their host plant occurs through mechanisms of bacterial motility, the growth of roots or by mechanisms which allow the colonization passively. Bacterial motility occurs by the process of chemotaxis, in which the movement of bacteria to the plant roots occurs by the attraction to the root exudates (carbon source) existing between soil and rhizosphere $\left(^{3,15}\right)$.

The colonization can occur from the initial recognition between endophyte and plant, by a reversible adsorption process or by an irreversible adhesion mediated by extracellular proteins synthesized by the bacteria and controlled by chemical signals emitted by the roots of the host plant. After colonization, the survival of the organism is influenced by biotic and abiotic factors. This survival is positively related to the physicochemical parameters of the soil and the content of organic matter and nitrogen. As the result of the colonization of the rhizosphere, the endophytic bacteria proliferate in the internal plant tissues, finding more stable and protected niches in these spaces $\left({ }^{15}\right)$.

Colonization capacity of endophytic microorganisms and the allocation of resources within the plant are factors that interfere in endophytic distribution. Thus, the different plant tissues may have different composition in the endophytic community $\left({ }^{34}\right)$. Some bacterial genera can induce defense mechanisms in plants, making it difficult the colonization by other endophytes $\left({ }^{17}\right)$.

Endophytes, which are transmitted vertically by seeds, are often recovered as epiphytes, suggesting that endophytes may also colonize surrounding environments of host plants. The colonization behavior of endophytes depends on many variables, including plant tissue type, plant genotype, taxon and strain type, as well as biotic and abiotic environmental conditions. Many bacterial endophytes originate from the rhizosphere environment, which attracts microorganisms due to the presence of root exudates and 
through root colonization. To some extent, stem and leaf surfaces also produce exudates that attract microorganisms. However, UV light, lack of nutrients and desiccation generally reduce colonization of leaf surfaces $\left({ }^{38}\right)$.

\section{MECHANISMS USED BY ENDOPHYTIC BACTERIA TO PROMOTE PLANT GROWTH}

The endophytic bacteria are a group of microorganisms responsible for promoting plant growth and have three metabolic pathways that result in the plant development. They are phytostimulation, biofertilization and biological control and are interrelated in physiological processes of the plant $\left({ }^{34}\right)$. Below, each of these mechanisms and their importance in plant physiology will be described.

\section{Phytostimulation}

Phytostimulation is the production of phytohormones, which act as regulators of plant growth $\left({ }^{39}\right)$. Phytohormones known as auxins, cytokinins and gibberellins promote morphological changes of roots, influencing the absorption of nutrients and water $\left({ }^{15,40}\right)$. Among the group of auxins, the enzyme ACC deaminase (1-aminocyclopropane-1carboxylic acid) reduce ethylene levels. When the level of this substance is high, it can result in inhibition of cell division, DNA synthesis, growth of roots and aerial parts of the plant. Endophytes use ACC deaminase enzyme and indoleacetic acid (IAA) to reprogram certain signaling pathways, influencing in the endophytic community structure $\left({ }^{34}\right)$. The modulating in ethylene levels results in root growth and promotes seed germination $\left({ }^{15}\right)$.

Bacteria such as Acinetobacter sp., Azospirillum sp., Azotobacter sp., Pseudomonas sp. and Bacillus sp. produce phytohormones such as indoleacetic acid, indolebutyric acid, gibberellins, cytokinins, octadecanoids and compounds that mimic the action of jasmonates, and assist in survival of the plant. Control of opening and closing of stomata, osmotic adjustment, modification of root morphology, photosynthetic efficiency, increased uptake and modification of mineral buildup, supply of essential vitamins, and nitrogen metabolism are examples of benefits related to the association between endophytes and plants $\left({ }^{11}\right)$.

The inoculation of the endophytic Bacillus sp. barely resulted in a significant increase in the content of manganese, zinc and copper $\left({ }^{41}\right)$. After inoculating Bacillus pumilus, Chryseobacterium indologenes and Acinetobacter johnsonii in beet, a higher concentration of carbohydrates in the plant was observed, as a result of their greater photosynthetic capacity by the increase in chlorophyll content $\left({ }^{20}\right)$.

\section{Biofertilization}

In biofertilization, plant growth is promoted by the bioavailability of nutrients. Endophytes are alternatives to maximize biological nitrogen fixation by plants, because these microorganisms have the capacity of colonizing structures such as roots, stems and leaves of plants and suffer less competition than the bacteria present in soil $\left({ }^{42}\right)$.

In the process of biological nitrogen fixation, the endophytic bacteria assimilate atmospheric nitrogen and convert it into ammonia, transferring this molecule to the plant metabolism $\left({ }^{34}\right)$. A $30 \%$ increase in the nitrogen content in sugarcane has been observed after inoculation with a bacterial mixture of Gluconacetobacter diazotrophicus, Herbaspirillum seropedicae, H. rubrisubalbicans, Azospirillum amazonense and Burkholderia sp. $\left({ }^{43}\right)$.

The deficiency in phosphorus availability is considered a limiting factor to the plant development, and this nutritional restriction impacts agricultural income $\left({ }^{44,45}\right)$. For the solubilization of phosphorus, endophytic bacteria synthesize organic acids, increasing the availability of phosphorus to the plant $\left({ }^{34}\right)$. An increase in phosphatase activity and 
availability of phosphorus content in the vermicomposting technique has been observed by inoculating of B. silvatlantica, Bacillus sp. and H. seropedica. The authors affirm that organic acids (oxalic, citric and tartaric acids) synthesized by Burkholderia sp. are the main mechanisms involved in the solubilization of phosphorus $\left({ }^{46}\right)$.

The cycling of soil nutrients is essential for the sustainability of agricultural systems $\left({ }^{47}\right)$. The benefits of the dynamic of biogeochemical cycles, which result in the solubility of nitrogen, phosphate and zinc, sulfur oxidation, and nitrate bioavailability $\left({ }^{11}\right)$ are related to the bacterial community capacity to provide significant quantities of natural nutrients, which are often scarce, and result in soil enrichment $\left({ }^{44,45}\right)$.

\section{Biological Control}

Biological control is a mechanism that promotes plant growth by protecting against the attack of phytopathogens, mediated by the production of siderophores, antibiotics or bacteriocins $\left({ }^{34}\right)$. These mechanisms are effective against plant pathogens, for being able to minimize or avoid the proliferation of such microorganisms by antagonism $\left({ }^{39}\right)$.

Siderophores are molecules secreted by microorganisms when there is a low availability of iron in the soil. Siderophores secreted act in the solubilization of this iron in soil because they present high affinity in the substrate and the ability to absorb it. These molecules bind to specific receptors and are actively transported through the cell membrane of Gram-negative and Gram-positive bacteria. The availability of iron for plant growth occurs by the bacterial complex iron/siderophores and, conversely, these molecules limit the acquisition of iron by phytopathogens, preventing their proliferation $\left({ }^{15,39}\right)$.

The production of siderophores gives certain competitive advantages for plant growthpromoting bacteria existing in the rhizosphere because, when colonizing the roots, the endophytic bacteria end up excluding other existing microorganisms in this ecological niche. One example is the production of siderophores by Pseudomonas sp. which display high affinity for ferric ion $\left({ }^{39}\right)$.

The production of antibiotics is considered a very efficient mechanism for control of plant pathogens, because it occurs directly in cell metabolism. However, the effective action of an antibiotic against one pathogen strain may not have the same efficiency on another strain of the same species due to the presence of genetic resistance mechanisms, or the lost in efficiency because of varying environmental conditions $\left({ }^{15}\right)$.

The production of antibiotics by bacteria is associated with its ability to act as antagonist to combat plant pathogens. The antibiosis mechanisms, as well as the activities of biological control, from the synthesis of molecules that eliminate or inhibit the growth of pathogenic organisms, have become better understood with the improvement of researches. Species of Pseudomonas sp. and Bacillus sp. synthesize lipopeptides biosurfactants that are important in biological control because they show positive potential in competitive interactions with different groups of microorganisms, including nematodes and plants. Antibiotics isolated from a wide range of bacterial strains and fungi inhibit the cell wall synthesis of pathogens, influence the structure of the cell membrane and inhibit the formation of initiating complexes of the small subunit of the ribosome $\left({ }^{39}\right)$.

The selection process of endophytic bacteria to be used in order to act as agents in biological control should require them to be Gram-positive spore-forming bacteria, because these bacteria, among which are Bacillus spp. and Paenibacillus spp., have greater stability in the population in the steps of formulation and storage of inoculant products $\left({ }^{39}\right)$.

In Brazil, various researches are carried out aiming the biological control of plant diseases, such as of maize, wheat, beans and crucifers, as well as the post harvest control in pepper and apple $\left({ }^{47}\right)$. 
Endophytes can induce plant defense reactions, called induced systemic resistance (ISR) leading to greater tolerance to pathogens, and is recognized as a tool for disease management in modern agriculture. The interactions between beneficial microorganisms and plants trigger an immune response in plants similar to that caused by pathogens. Strains of the genera Pseudomonas and Bacillus can be considered the most common groups that induce ISR, although it is not exclusive to these groups $\left({ }^{48}\right)$. Another plant defense mechanism is systemic acquired resistance (SAR), which has a broad spectrum of action and long duration after elicitation $\left({ }^{49}\right)$. During the SAR responses obtained by necrotrophic pathogens, plants obtain not only systemic resistance against the inducing pathogen, but also to different classes of pathogens. One of the parallels between rhizobacterium-induced ISR and pathogen-induced SAR is that both types of induced resistance are effective against a broad spectrum of plant pathogens $\left({ }^{50,51}\right)$.

\section{CONCLUSIONS}

Endophytic bacteria help in the adaptation of the plants in various ecosystems and have a significant ecological importance because they improve the soil fertility and quality. Studies on the presence of endophytic bacteria in plants and the metabolic influence of these microorganisms in plant tissues enable us to understand the physiological and biochemical changes triggered by the endophyte/plant interactions.

Studies have shown that there is a great diversity of endophytic bacteria colonizing different plant structures, and various benefits are related to this interaction. These microorganisms are not subject to competition for nutrients, which normally occurs in the rhizosphere, and operate with greater efficiency in reducing damage caused by various phytopathogens.

The isolation and identification methods of endophytic bacteria are essential for the improvement of agricultural techniques, because many species promote plant growth, improved absorption of nutrients and stimulate resistance to environmental stress, thus constituting in important biological tools that impact positively agricultural production. Endophytes show great biotechnological potential and the study and selection of these microorganisms have the ability to biodegrade contaminants molecules, making them promising tools for bioremediation of environments degraded by pesticides.

Inoculation of endophytic bacteria in plants has economic importance, as it increases the yield of agricultural production and requires low-cost farming techniques, resulting in low environmental impact. Thus, it is necessary to improve management methods and application of endophytic bacteria to maximize the beneficial interactions provided by the association of these microorganisms with plants.

\section{ACKNOWLEDGMENT}

\section{CNPq, CAPES, FAPERGS, UNISINOS.}

\section{REFERENCES}

1. Acosta MBR, Duarte LGC. Pesquisa da existência de bactérias Gram negativas endofíticas potencialmente patogênicas para o homem em hortaliças provenientes de cultivos orgânicos. Rev Soc Vem Microbiol. 2014; 34(2): 59-63.

2. Assumpção LC, Lacava PT, Dias ACF. Diversidade e potencial biotecnológico da comunidade bacteriana endofítica de sementes de soja. Pesquisa Agropecuária Brasileira. v. 44, n.5, p. 503-510, 2009. 
3. Azevedo JL, Maccheroni Jr W, Pereira JO, Araújo WL. Endophytic microorganisms: a review on insect control and recent advances on tropical plants. Electron J Biotechn. 2000; 3(1): 40-65.

4. Xia Y, DeBolt S, Dreyer J, Scott D, Williams MA. Characterization of culturable bacterial endophytes and their capacity to promote plant growth from plants grown using organic or conventional practices. Front Plant Sci. 2015; 6: 490.

5. Msagati TAM, Mamba BB; Sivasankar V, Sakthivel R, Prabhakaran. 2015. Epdimiology and forecasting systems of plant pathogenic bacteria. In: Sustainable Approaches to Controlling Plant Pathogenic Bacteria, Ed. Kannak, R. and Bastas K.K. CRC Press, 405 páginas.

6. Azevedo JL. Microorganismos endofíticos. In: Ecologia Microbiana. Jaguariúna: Embrapa - CNPMA, São Paulo, Brasil. 1998.

7. Bary A. Morphologie und physiologie der Pilze. Flecthen und Mycomycetum, Engelman, Leipzig, 1866.

8. Hallmann J, Quadt-Hallmann A, Mahaffee WF, Kloepper JW. Bacterial endophytes in agricultural crops. Can J Microbiol. 1997; 43(10): 895-914.

9. Djordjevic MA, Gabriel DW, Rolfe BG. Rhizobium - the refined parasite of legumes. Annu Rev Phytopathol. 1987; 25: 145-168.

10. Santos JF, Sacramento BL, Mota KNAB, Souza JT, Neto ADA. Crescimento de girassol em função da inoculação de sementes com bactérias endofíticas. Pesquisa Agropecuária Tropical. 2014; 44(2): 142-150.

11. Polesi NPE. Microrganismos endofíticos e a cultura de tecidos vegetais: quebrando paradigmas. Revista Brasileira de Biociências. 2011; 9(4): 533-541.

12. Aravind R, Eapen SJ, Kumar A, Dinu A, Ramana KV.Screening of endophytic bacteria and evaluation of selected isolates for suppression of burrowing nematode (Radopholus similis Thorne) using three varieties of black pepper (Piper nigrum L.). Crop Prot. 2010; 29(4): 318-324.

13. Costa FEC, Melo IS. Endophytic and rhizospheric bacteria from Opuntia ficus-indica mill and their ability to promote plant growth in cowpea, Vigna unguiculata (L.) Walp. Afr J Microbiol Res. 2012; 6(6): 1345-1353.

14. Hardoim PR, van Overbeek LS, Elsas JD. Properties of bacterial endophytes and their proposed role in plant growth. Trends Microbiol. 2008; 16(10): 463-471.

15. Oliveira ALM, Urquiaga s, Baldani JI, Processos e mecanismos envolvidos na influência de microrganismos sobre o crescimento vegetal. Embrapa Agrobiologia, Documentos 161. 2003.

16. Compant S, Kaplan H, Sessitsch A, Nowak J, Ait Barka E, Clément C. Endophytic colonization of Vitis vinifera L. by Burkholderia phytofirmans strain PsJN: from the rhizosphere to inflorescence tissues. FEMS Microbiol Ecol. 2008; 63(1): 84-93.

17. Chebotar VK, Malfanova NV, Shcherbakov AV, Ahtemova GA, Borisov AY, Lugtenberg B, Tikhonovich IA. Endophytic Bacteria in Microbial Preparations that Improve Plant Development. Appl Biochem Microbiol. 2015; 51(3): 283-289.

18. Guimarães SL, Baldani VLD. Produção de arroz inoculado com bactérias diazotróficas marcadas com resistência induzida ao antibiótico estreptomicina. Rev Bras Ciênc Agrár. 2013; 56(2): 125-132.

19. Bao Z, Sasaki K, Okubo T, Ikeda S, Anda M, Hanzawa E, Kakizaki K, Sato T, Mitsui H, Minamisawa K. Impact of Azospirillum sp. B510 inoculation on rice-associated bacterial communities in a paddy field. Microbes Environ. 2013; 28(4): 487-490.

20. Shi Y, Lou K, Li C. Growth and photosynthetic efficiency promotion of sugar beet (Beta vulgaris L.) by endophytic bacteria. Photosynthesis Research. 2010; 105(1): 513.

21. Gírio LAS, Dias FLF, Reis VM, Urquiaga S, Schultz N, Bolonhezi D, Mutton MA. Bactérias promotoras de crescimento e adubação nitrogenada no crescimento inicial de cana-de-açúcar proveniente de mudas pré-brotadas. PAB. 2015; 50(1): 33-43.

22. Pereira W, Leite JM, Hipólito GS, Santos CLR, Reis VM. Acúmulo de biomassa em variedades de cana-de-açúcar inoculadas com diferentes estirpes de bactérias diazotróficas. Rev Cienc Agron. 2013; 44(2): 363-370.

23. Beneduzi A, Moreira F, Costa PB, Vargas LK, Lisboa BB, Favreto R, Baldani JI, Passagli LMP. Diversity and plant growth promoting evaluation abilities of bacteria 
isolated from sugarcane cultivated in the South of Brazil. Appl Soil Ecol. 2013; 63: 94104.

24. Zakria M, Ohsako A, Saeki Y, Yamamoto A, Akao S. Colonization and growth promotion characteristics of Enterobacter sp. and Herbaspirillum sp. on Brassica oleracea. Soil Sci Plant Nutr. 2008; 54(4): 507-516.

25. Ambrosini A, Beneduzi A, Stefanski T, Pinheiro FG, Vargas LK, Passaglia LMP. Screening of plant growth promoting rhizobacteria isolated from sunflower (Helianthus annuus L.). Plant Soil. 2012; 356(1): 245-264.

26. Ferreira AS, Pires RP, Rabelo PG, Oliveira RC, Luz JMQ, Brito CH. Implications of Azospirillum brasilense inoculation and nutrient addition on maize in soils of the Brazilian Cerrado under greenhouse and field conditions. Appl Soil Ecol. 2013; 72: 103-108.

27. Wang Y, Li H, Zhao W, He X, Chen J, Geng X, Xiao M. Induction of toluene degradation and growth promotion in corn and wheat by horizontal gene transfer within endophytic bacteria. Soil Biology e Biochemistry. 2010; 42(7): 1051-1057.

28. Shiomi HF, Melo IS, Minhoni MTA. Seleção de bactérias endofíticas com ação antagônica a fitopatógenos. Scientia Agraria. 2008; 9(4): 535-538.

29. Hungria M. Inoculação com Azospirillum brasilense: inovação em rendimento a baixo custo. Embrapa Soja, Documentos 325. 2011.

30. Sharma SB, Sayyed RZ, Trivedi MH, Gobi TA. Phosphate solubilizing microbes: Sustainable approach for managing phosphorus deficiency in agricultural soils. Springer Plus. 2013; 2(587): 1-14.

31. Hungria M, Nogueira MA, Araujo RS. Co-inoculation of soybeans and common beans with rhizobia and azospirilla: Strategies to improve sustainability. Biol Fert Soils. 2013; 49(7): 791-801.

32. Upadhyay SK, Singh JS, Saxena AK, Singh DP. Impact of PGPR inoculation on growth and antioxidant status of wheat under saline conditions. Plant Biology. 2012; 4(14): 605-611.

33. Andreote FD, Durrer TGA. Exploring interactions of plant microbiomes. Sci Agric. 2014; 71(6): 528-539.

34. Gaiero JR, McCall CA, Thompson KA, Day NJ, Best AS, Dunfield KE. Inside the root microbiome: bacterial root endophytes and plant growth promotion. Am J Bot. 2013; 100(9): 1738-1750.

35. Carvalho TLG, Balsemão-Pires E, Saraiva RM, Ferreira PCG, Hemerly AS. Nitrogen signalling in plant interactions with associative and endophytic diazotrophic bacteria. $\mathrm{J}$ Exp Bot. 2014.

36. Barbosa JZ, Consalter R, Vezzani FM, Motta ACV. Bactérias e fungos benéficos na endosfera das plantas. Rev Agrogeoambiental. 2015; 7(3): 99-116.

37. Reis VM, Olivares FL. Vias de penetração e infecção de plantas por bactérias. Embrapa, Comunicado Técnico 126. 2006.

38. Hardoim PR, van Overbeek LS, Berg G, Pirttilä AM, Compant S, Campisano A, Döring M, Sessitsch A. 1 July 2015. The hidden world within plants: ecological and evolutionary considerations for defining functioning of microbial endophytes. Microbiol Mol Biol Rev doi:10.1128/MMBR.00050-14.

39. Beneduzi A, Ambrosini A, Passaglia LMP. Plant growth-promoting rhizobacteria (PGPR): Their potential as antagonists and biocontrol agents. Genet Mol Biol. 2012; 35(4): 1044-1051.

40. Moreira FMS, Silva K, Nobrega ARS, Carvalho F. Bactérias diazotróficas associativas: diversidade, ecologia e potencial de aplicações. Com Sci. 2010; 1(2): 74-99.

41. Canbolat MY, Bilen S, Çakmakç R, Şahin F, Aydın A. Effect of plant growthpromoting bacteria and soil compaction on barley seedling growth, nutrient uptake, soil properties and rhizosphere microflora. Biol Fertil Soils 2006; 42(4): 350-357.

42. Balachandar D, Sandhiya GS, Sugitha TCK, Kumar K. Flavonoids and growth hormones influence endophytic colonization and in planta nitrogen fixation by a diazotrophic Serratia sp. in rice. World J Microbiol Biotechnol. 2006; 22(7): 707-712.

43. Oliveira ALM, Urquiaga S, Döbereiner J, Baldani JI. The effect of inoculating endophytic $\mathrm{N}_{2}$ fixing bacteria on micropropagated sugarcane plants. Plant Soil. 2002; 242(2): 205-215 
44. Khan MS, Zaidi A, Wani PA. Role of phosphate-solubilizing microorganisms in sustainable agriculture: a review. AGSO. 2007; 27: 29-43.

45. Dias ACF, Costa FEC, Andreote FD, Lacava PT, Teixeira MA, Assumpção LC, Araújo WL, Azevedo JL, Melo IS. Isolation of micropropagated strawberry endophytic bacteria and assessment of their potential for plant growth promotion. World J Microb Biot. 2009; 25(2): 189-195.

46. Busato JG, Lima LS, Aguiar NO, Canellas LP, Olivares FL. Changes in labile phosphorus forms during maturation of vermicompost enriched with phosphorussolubilizing and diazotrophic bactéria. Bioresour Technol. 2012; 110: 390-395.

47. Mariano RLR, Silveira EB, Assis SMP, GOMES AMA, Nascimento ARP, Donato VMTS. Importância de bactérias promotoras de crescimento e de biocontrole de doenças de plantas para uma agricultura sustentável. Anais da Academia Pernambucana de Ciência Agronômica. Recife. 2004; 1: 89-111.

48. Yi H-S, Yang JW and Ryu C-M. 2013. ISR meets SAR outside: additive action of the endophyte Bacillus pumilus INR7 and the chemical inducer, benzothiadiazole, on induced resistance against bacterial spot in field-grown pepper. Front. Plant Sci. 4:122. doi: 10.3389/fpls.2013.00122

49. Van Loon LC; Bakker PAHM; PIETERSE CMJ. Systemic resistance induced by rhizosphere bacteria. Annu. Rev. Phytopathol. 36:453-83. 1998.

50. Tuzun S; Kuc J. Plant immunization: an alternative to pesticides for control of plant diseases in the greenhouse and field. Technical Bulletin-Food and Fertilizer Technology Center, 124: 111991

51. Hammerschmidt R. (2009). Systemic acquired resistance. Adv. Bot. Res. 51 173-222 